\title{
АНАЛІЗ КАДРОВОГО ЗАБЕЗПЕЧЕННЯ ТА ПРИНЦИПІВ ПІДГОТОВКИ ФАХІВЦІВ ДЛЯ СЛУЖБИ ГРОМАДСЬКОГО ЗДОРОВ'Я В УКРАЇНІ
}

\author{
Національний медичний університет ім. О.О. Богомольця, м. Київ, Україна
}

\begin{abstract}
Мета: обґрунтування кадрового забезпечення служби громадського здоров'я України в умовах реформування галузі.

Матеріали і методи. Вивчалися дані державної статистичної звітності, бази «ЗДВ» Європейського регіонального бюро ВОО3, World Health Statistics 2016. Використано методи: статистичний, бібліосемантичний, експертних оцінок, системного підходу.

Результати. Аналіз кадрового забезпечення охорони здоров'я України свідчить про скорочення показників забезпечення населення лікарями, у т.ч. спеціалістами санітарно-гігієнічного та епідеміологічного профрілю. Впродовж 2010-2015 рр. забезпеченість лікарями зменшилася на 16,3\%, у т.ч. санітарними лікарями - на 14,7\%.

На основі аналізу контингенту студентів, які навчалися в 2015 р. за спеціальністю «Медико-просрілактична справа» у ВМНЗ України на додипломному рівні, було встановлено, що план підготовки за державним замовленням протягом останніх трьох років зменшено майже втричі. Спеціальність «Громадське здоров'я» включено до переліку галузей знань і спеціальностей, за якими здійснюється підготовка здобувачів вищої освіти. Проте підготовка магістрів громадського здоров'я здійснюється лише в одному немедичному ВНЗ України, лише за спеціальністю «Менеджмент організацій і адміністрування (в охороні здоров'я)», що не забезпечує сучасні потреби галузі та суспільства.
\end{abstract}

Аналіз європейського досвіду виявив, що в країнах Європейського союзу відсутня єдина програма підготовки таких фрахівців, а посадові обов'язки і фрахові вимоги для підготовки спеціалістів суттєво відрізняються в кожній окремій країні.

Висновки. 3 огляду на існуючі виклики і загрози для громадського здоров'я, глобальні тенденції та національний контекст, необхідним є фрормування нових інституційних структур з підготовки фрахівців громадського здоров'я, обґрунтування і розробка нових навчальних планів підготовки магістрів громадського здоров'я.

КЛЮЧОВІ СЛОВА: служба громадського здоров'я, кадрове забезпечення, санітарний лікар, підготовка кадрів.

Профрілактична медицина в системі охорони здоров'я в сучасному суспільстві набуває особливої значущості. Громадське здоров'я в XXI ст. розглядається в площині планетарних масштабів. Всесвітня організація охорони здоров'я (ВОО3), Фонд народонаселення Організації Об'єднаних Націй (ФН ООН), Товариство Червоного Хреста, Дитячий фонд ООН (ЮНІСЕФ) акцентують увагу на глобальному характері проблем збереження здоров'я населення. Низька фрізична активність, тютюнопаління, нерівність у забезпеченні медичною допомогою, несприятливі соціально-економічні умови, високі рівні смертності, поширеності неінфекційних захворювань, поліморбідність - це те, з чим стикаються різною мірою фрахівці системи громадського здоров'я кожної країни. Проблеми антибіотико- та хіміорезистентності бактерій, постаріння населення, значні рівні поширеності гіпертонічної хвороби, цукрового діабету та їх ускладнень, дисліпідемії, онкологічних захворювань вимагають пошуку ефективних ключів для їх подолання.
Реорормування охорони здоров'я в Україні належить до пріоритетних завдань внутрішньої політики. Держава визначає здоров'я населення однією 3 найбільших цінностей, необхідним компонентом розвитку та соціально-економічного процвітання України [9].

Національна стратегія реформування системи охорони здоров'я України на період 2015-2020 рр. серед короткострокових цілей (на 2015-2016 рр.) передбачає формування системи громадського здоров'я (СГЗ) на основі відповідного законодавства [13, С.37]. Після ліквідації санітарно-епідеміологічних станцій планується «переорієнтувати систему... на підвищення відповідальності за збереження здоров'я та промоцію здорового способу життя, зміцнення соціальної свідомості та формування готовності протистояти надзвичайним подіям у сорері громадського здоров'я, наприклад, епідеміям» [13, С.24].

Пошук оптимальних моделей організації та фрункціонування СГЗ знаходиться в центрі уваги суспільства. У рамках реалізації Угоди про

() Т.С. Грузєва, Л.І. Галієнко, О.Я. Антонюк, С.В. Власенко, 2017 
асоціацію між Україною та ЄС актуалізується питання щодо ефективності санітарно-епідеміологічного нагляду, створення Центру громадського здоров'я, профрільних наукових громадських організацій. Концепція розвитку СГЗ в рамках реформування медичної галузі передбачає консолідацію аналітичних, дослідних, лабораторних установ Міністерства охорони здоров'я України (МО3) та створення єдиного Центру громадського здоров'я МO3 України шляхом об'єднання існуючих установ і закладів МО3 та Державної санітарно-епідеміологічної служби (ДСЕС) України [9].

Розділ 22 Угоди про асоціацію між Україною та ЄС присвячений проблемам зміцнення громадського здоров'я. Подальший розвиток галузі має здійснюватися відповідно до Європейського плану дій щодо зміцнення потенціалу та послуг громадського здоров'я, який пропонує набір із 10 горизонтальних оперативних фрункцій громадського здоров'я, що можуть стати єднальною основою для всіх зацікавлених сторін відносно встановлення, моніторингу та оцінки заходів політики, стратегії і дій зі зміцнення громадського здоров'я [13;19].

Україна взяла зобов'язання розвивати співробітництво у сфрері охорони здоров'я 3 метою підвищення рівня його безпеки та захисту здоров'я людини як передумови сталого розвитку та економічного зростання, у т.ч. керуючись підходом «охорона здоров'я у всіх політиках» держави [4;14].

Отже, крім відповідних змін законодавства та організаційних заходів стає особливо актуальним питання кадрового забезпечення галузі, підготовки фрахівців для СГЗ.

Метою роботи є обґрунтування підходів до кадрового забезпечення СГЗ України в умовах реформування галузі.

Для досягнення мети необхідно виконати наступні завдання: здійснити ретроспективне дослідження забезпеченості закладів ДСЕС України спеціалістами санітарно-гігієнічного та епідеміологічного профрілю; проаналізувати контингент студентів, які навчаються за спеціальністю «Медико-профрілактична справа» у ВМНЗ України (за державним замовленням) на додипломному рівні; вивчити європейський досвід визначення потреби в кадрах для СГЗ.

Матеріали та методи. Інформаційною базою дослідження стали матеріали державної статистичної звітності, база даних Європейського регіонального бюро ВООЗ «Здоров'я для всіх», World Health Statistics, 2016. Використано наступні методи: статистичний, бібліосемантичний, епідеміологічний, моделювання, експертних оцінок, системного підходу.

Результати дослідження та їх обговорення. Проблеми збереження санітарно-епідеміологічного благополуччя, протидії інфекційним захворюванням розглядаються з позицій безпеки держави.
Глобальні загрози у сфері громадського здоров'я включають: захворювання, здатні викликати епідемії; захворювання, пов'язані із забрудненням харчових продуктів; випадкові або навмисно викликані спалахи хвороб (біотероризм); радіаційні аварії; екологічні катастрофи [2, С.243]. При цьому основною фрункцією держави у сорері громадського здоров'я повинна бути розробка політики і стратегії профрілактики захворювань, охорони та промоції здоров'я.

Відповідно до Національної стратегії реформування системи охорони здоров'я України на період 2015-2020 рр., держава буде ініціатором та сприятиме громадським ініціативам, що спрямовані на зменшення впливу критичних фракторів ризику для здоров'я. Крім того, визначено такі пріоритети громадського здоров'я, як нагляд та моніторинг захворюваності, реагування на спалахи хвороб, вакцинація, лабораторна діагностика загроз для здоров'я, безпечність води, харчових продуктів і середовища життєдіяльності (включаючи вплив чинників навколишнього середовища та виробництва) [13]. Тобто передбачається здійснення санітарного нагляду, виконання інформаційноаналітичних функцій, а також перегляд існуючих та розробка нових санітарних правил та норм.

Система громадського здоров'я також орієнтована на профілактику туберкульозу, ВІЛ-інфрекції, вірусних гепатитів, які визначено як пріоритети громадського здоров'я.

Здоров'я матері та дитини, репродуктивне та психічне здоров'я повинні бути відображеними у стратегічному плані розвитку громадського здоров'я [13].

Національна стратегія рефрормування системи охорони здоров'я України на період 2015-2020 рр. передбачає створення Національного центру контролю за захворюваннями і громадським здоров'ям шляхом злиття закладів та установ, а створення регіональних (обласних) центрів громадського здоров'я та єдиної лабораторної мережі реагування на загрози у даній сфрері забезпечить формування регіональної структури СГЗ [13].

Враховуючи багатовекторність завдань СГЗ, стає зрозумілою важливість аналізу існуючого кадрового потенціалу галузі, а також можливостей підготовки фрахівців для охорони здоров'я в цілому і служби громадського здоров'я зокрема. До проблеми кадрового забезпечення охорони здоров'я неодноразово зверталися науковці [1;4;6;7;10-12;18].

Аналіз статистичних даних свідчить, що забезпеченість лікарями (фрізичними особами) у 2015 р. становила 38,0 на 10 тис. нас., тоді як у 2010 р. вона дорівнювала 43,2 на 10 тис. нас. [20, С.347]. Таким чином, забезпеченість лікарями скоротилася на 12\%, що відповідає скороченню кількості штатних лікарських посад у закладах системи МО3 України. Так, кількість штатних лікарських посад у 
2010 р. була 234,9 тис., а в 2015 р. - 196,8 тис. відповідно (темп скорочення склав 16,3\%).

У цілому в Україні кількість лікарів за звітний період зменшилася на 35444 особи, тобто на 18\% [9, С.347]. При цьому рівень укомплектованості штатних посад лікарів фрізичними особами на 2015 р. залишається стабільно досить низьким 82,14\% (для порівняння: у 2010 р. - 80,8\%) [9, С.350].

За статистичними даними ВОО3, у країнах Європейського регіону забезпеченість лікарями $€$ найнижчою в Албанії (11,4 на 10 тис. нас.), а найвищою - у Монако (71,67 на 10 тис. нас.), тоді як в Україні вона становить 35,43 на 10 тис. нас. (2013), що відповідає середньоєвропейському рівню (32,3 на 10 тис. нас.) [29].

Питома вага лікарів санітарної групи у загальній чисельності лікарів становила в 2010 р. 4,1\%, а в 2015 р. - 3,98\% [20, С. 350]. Відповідно забезпеченість лікарями санітарної групи у 2010 р. складала 1,77 на 10 тис. нас., а в 2015 р. - 1,51 на 10 тис. населення.
За даними В.В. Мельник (2015 р.), загальна чисельність лікарів закладів ДСЕС України у 20012012 рр. скоротилася 3 10,6 тис. осіб до 7,7 тис. осіб, або на 27,4\% [10, С.9].

Цікавим є досвід іноземних колег щодо визначення потреби в кадровому забезпеченні СГЗ. Так, М. Jambroes та співавт. (Нідерланди, 2015) запропонували планувати потребу в кадрових ресурсах у сорері громадського здоров'я з метою подальшої розробки політики в СГЗ на основі послуг, що надаються. Вчені зазначають: «якщо існуючі джерела даних не містять необхідну інформацію, або мають дані щодо частини робочої сили, то потрібно збирати первинні дані» [26]. Метою їхнього дослідження було розробити стратегію для перерахунку та опису кадрових ресурсів для громадського здоров'я на основі виконання основних операцій у сорері охорони здоров'я і застосувати цей принцип до розрахунку потреби в кадрових ресурсах ГЗ в Нідерландах у якості прикладу [26] (табл. 1).

\section{Таблиця 1. Основні операції у сфері громадського здоров'я в Нідерландах}

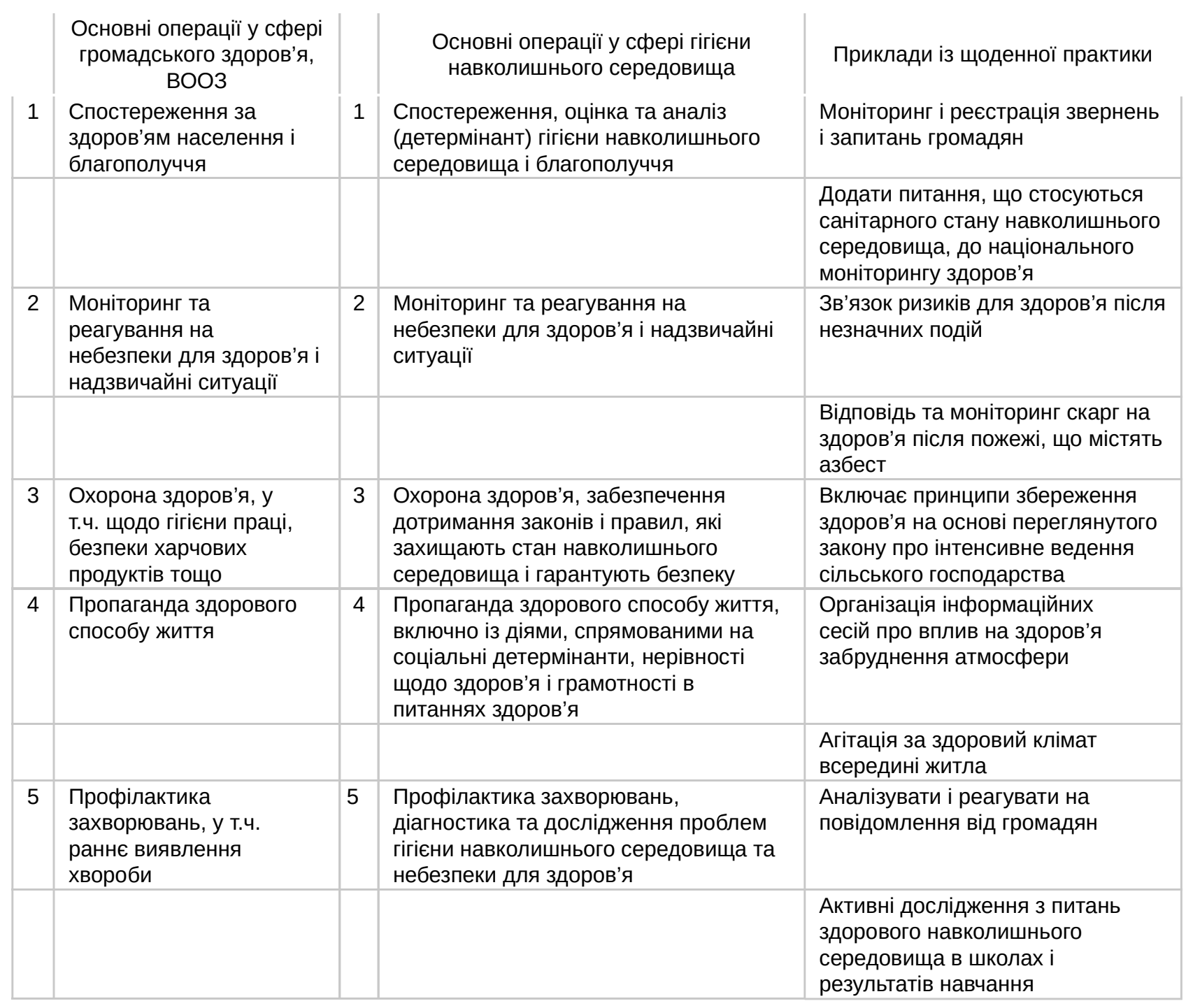


Продовження табл. 1

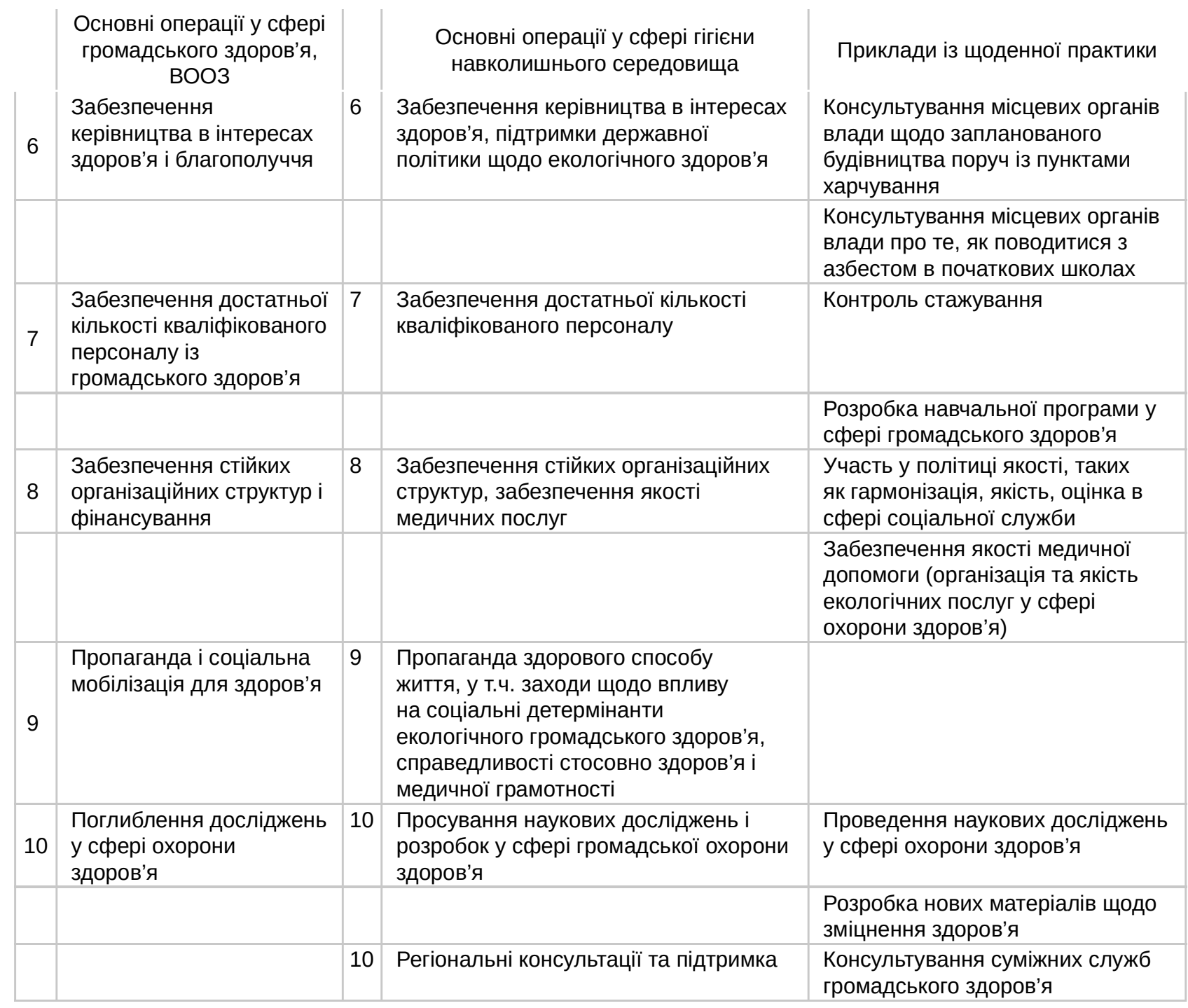

M. Jambroes зі співавт. провели опитування фрахівців громадського здоров'я і на основі відповідей респондентів визначили час, який витрачається на виконання вищевказаних операцій. Робочий час 36 год. на тиждень (1 FTE) відповідав одній зайнятій посаді спеціаліста із ГЗ. Сумарне навантаження на працівників оцінювалося в 110 FTE (інтервал 79-152 FTE), або 0,66 посади на 100 тис. населення. Таким чином, науковці запропонували новий метод розрахунку потреби в кадровому забезпеченні СГЗ. На нашу думку, досвід M. Jambroes та співавт. міг би бути корисним при розрахунку потреби в підготовці фрахівців для СГЗ в Україні в сучасних умовах.

Враховуючи вищезазначене, актуалізується проблема підготовки кадрів для СГЗ на до- і післядипломному рівнях. Станом на 2015 р. в Україні за державним замовленням за спеціальністю «Медико-профрілактична справа» навчалося 1897 студентів (з них 1367 (72\%) були студентами IV-VI курсів) (табл. 2) [18]. План підготовки за державним замовленням було скорочено протягом останніх трьох років майже втричі, а тому контингент студентів і в подальшому буде різко зменшуватися. Не у всіх ВМНЗ України на даний момент здійснювалася підготовка за спеціальністю «Медико-профрілактична справа». Спеціальність «Громадське здоров'я» включено до нового переліку галузей знань і спеціальностей, за якими здійснюється підготовка здобувачів вищої освіти (постанова Кабінету Міністрів України №53 від 01.02.2017р.) [16].

У світі підготовка фрахівців за спеціальністю «Громадське здоров'я» має три ступені: бакалавр, магістр та доктор фрілософії (табл. 3).

Глобальне здоров'я, епідеміологія неінфекційних захворювань, економіка охорони здоров'я, біостатистика, медицина праці $€$ окремими навчальними дисциплінами, що вивчаються у світі на до- і післядипломному рівнях. Орієнтовний зміст навчальних програм із громадського здоров'я включає: біостатистику, епідеміологію, гігієну навколишнього середовища (Environmental Health), політику та управління охороною здоров'я, 
Таблиця 2. Контингент студентів, які навчаються за спеціальністю «Медико-профрілактична справа» у ВМНз України (за державним замовленням)

\begin{tabular}{|c|c|c|c|c|c|c|c|c|}
\hline \multirow{2}{*}{ № } & \multirow{2}{*}{ Назва ВМН3 } & \multicolumn{6}{|c|}{ Курси } & \multirow{2}{*}{ Всього } \\
\hline & & 1 & 2 & 3 & 4 & 5 & 6 & \\
\hline 1 & $\begin{array}{l}\text { Д3 «Дніпропетровська медична академія } \\
\text { Міністерства охорони здоров'я України» }\end{array}$ & 29 & 28 & 28 & 98 & 83 & 88 & 354 \\
\hline 2 & $\begin{array}{l}\text { Донецький національний медичний університет } \\
\text { імені М. Горького }\end{array}$ & 0 & 3 & 4 & 11 & 25 & 16 & 59 \\
\hline 3 & $\begin{array}{l}\text { Львівський національний медичний університет } \\
\text { імені Данила Галицького }\end{array}$ & 30 & 30 & 31 & 91 & 91 & 83 & 357 \\
\hline 4 & $\begin{array}{l}\text { Національний медичний університет імені } \\
\text { О.О. Богомольця }\end{array}$ & 50 & 57 & 58 & 147 & 148 & 124 & 584 \\
\hline 5 & Одеський національний медичний університет & 24 & 25 & 24 & 53 & 53 & 41 & 220 \\
\hline 6 & $\begin{array}{l}\text { ДВНЗ «Тернопільський державний медичний } \\
\text { університет ім. І.Я. Горбачевського МОЗ України» }\end{array}$ & 0 & 0 & 0 & 1 & 0 & 0 & 1 \\
\hline 7 & Харківський національний медичний університет & 35 & 35 & 38 & 62 & 79 & 73 & 322 \\
\hline \multicolumn{2}{|c|}{ УСьОГО } & 168 & 179 & 183 & 463 & 479 & 425 & 1897 \\
\hline
\end{tabular}

Таблиця 3. Форми та терміни навчання в процесі підготовки фахівців громадської охорони здоров'я у світі

\begin{tabular}{|l|l|l|l|}
\hline \multicolumn{1}{|c|}{ Форма навчання } & \multicolumn{1}{|c|}{ Ступінь } & \multicolumn{1}{|c|}{ Термін } & \multicolumn{1}{|c|}{ Кредити } \\
\hline Бакалаврат & Бакалавр (BSc) & 3-4 роки & $180-200$ \\
\hline Магістратура & $\begin{array}{l}\text { Професійна підготовка } \\
\text { Магістр (Master of Public Health (MPH) } \\
\text { Наукове дослідження } \\
\text { Магістр наук (Маster of Science (MSc) }\end{array}$ & $1,5-2$ роки & $90-120$ \\
\hline Аспірантура & $\begin{array}{l}\text { Професійна підготовка } \\
\text { Доктор громадського здоров'я (Doctor of Public Health (DrPH) } \\
\text { Наукове дослідження } \\
\text { Доктор фрілософії (Doctor of Philosophy (PhD) }\end{array}$ & 3-4 роки & \\
\hline $\begin{array}{l}\text { Курси, тренінги, } \\
\text { майстер-класи }\end{array}$ & & $\begin{array}{l}\text { Різна } \\
\text { тривалість }\end{array}$ & \\
\hline
\end{tabular}

соціальні і психологічні науки, соціальні детермінанти і нерівність стосовно здоров'я, міжвідомчу і колективну роботу, медичні технології, основні оперативні функції громадського здоров'я, концепцію психічного здоров'я, зміцнення здоров'я, менеджмент у сорері громадського здоров'я, наукові дослідження.

В Україні існує одна магістерська програма (МП) за спеціальністю 8.03060101 «Менеджмент організацій і адміністрування (в охороні здоров'я)» на базі Національного університету «Києво-Могилянська академія». Навчальний план підготовки студентів за даною МП включає низку навчальних дисциплін. Ліцензований обсяг на денну фрорму навчання передбачає навчання протягом 1 року 10 міс. 50 студентів за МП, що є недостатнім для кадрового забезпечення СГЗ.

Дисципліни, що пропонуються для вивчення за магістерською програмою 8.03060101 МП «Менеджмент організацій і адміністрування (в охороні здоров 'я)» обсягом 120 кредитів на першому році навчання включають англійську мову, вступ до охорони здоров'я, економіку охорони здоров'я, епідеміологію, методологію та організацію наукових досліджень, системи охорони здоров я, статистику в охороні здоров я, правове регулювання охорони здоров я, аналіз політики в охороні здоров я, менеджмент, логістику організацій охорони здоров я, забезпечення якості в охороні здоров я та операційний менеджмент. Також навчальним планом передбачено виробничу практику та технологію підготовки дослідницького проекту.

На другому році навчання в програму включено інорормаційні системи і технології в управлінні організацією, менеджмент персоналу, основи медичного права, маркетинг в охороні здоров'я. Після закінчення навчання передбачено переддипломну практику.

В Європейському Союзі немає універсальної програми підготовки фрахівців СГЗ. Так, дослідники під керівництвом Bernd Rechel i Martin McKee (2014) [23] зазначають, що огляд навчальних планів підготовки фрахівців СГЗ 15 країн Європейського Союзу виявив, що немає спільного визначення «еnvironmental health» (гігієна навколишнього середовища - авт.), так само як і відсутній договір в Європі щодо підготовки цих спеціалістів чи потреб у них (Public Health Services Gelderland Midden 2011) [23]. 
Підготовка спеціалістів, залучених у сореру гігієни навколишнього середовища, суттєво відрізняється в усіх європейських країнах, і відсутній спільний навчальний план їх підготовки. У Фінляндії, наприклад, спеціально не готують фрахівців 3 гігієни навколишнього середовища, а лише здійснюється навчання лікарів за фрахом «медицина праці» («осcupational health»), а також залучають до роботи інших спеціалістів, що вивчають гігієну навколишнього середовища і здоров'я [23, С.101]. у Нідерландах спеціальність «environmental health» для лікарів була заснована наприкінці 1980-х рр. і фахівців готують $з$ 1990-х рр. У Бельгії ця спеціальність охоплює також питання психології і біології. У Польщі Центр підготовки фрахівців 3 гігієни навколишнього середовища був заснований, але там здійснюється навчання лікарів загальної практики і педіатрів (Public Health Services Gelderland Midden 2011) [23].

Цілі навчання, так само як і рівні компетентності фрахівців з громадського здоров'я, також суттєво відрізняються в різних країнах. Усе це вказує на нагальну потребу щодо посилення співпраці і гармонізації в Європі, як по відношенню до навчальної програми підготовки гігієністів, так і щодо визначення напрямів роботи і ролей, а також реєстрації фрахівців (Public Health Services Gelderland Midden 2011) [23].

Отже, огляд навчальних програм підготовки лікарів, які опікуються громадським здоров'ям у різних країнах, показав, що вони не $є$ універсальним і мають значні відмінності. Безперечно, підготовка сучасних фрахівців з громадського здоров'я вимагає не просто корекції існуючих навчальних програм, але й фрормування нових інституційних структур і створення нових навчальних планів підготовки магістрів з урахуванням сучасних світових тенденцій та національних особливостей.

\section{Висновки}

Аналіз кадрового забезпечення охорони здоров'я України свідчить про скорочення показників забезпеченості населення лікарями, у т.ч. спеціалістами санітарно-гігієнічного та епідеміологічного профрілю. Упродовж 2010-2015 рр. забезпеченість лікарями зменшилася на 16,3\%, у т.ч. санітарними лікарями - на 14,7\%.

На основі аналізу контингенту студентів, які навчалися в 2015 р. за спеціальністю «Медикопрофрілактична справа» у ВМНЗ України на додипломному рівні, було встановлено, що план підготовки за державним замовленням протягом останніх трьох років зменшено майже втричі. Спеціальність «Громадське здоров'я» включено до переліку галузей знань і спеціальностей, за якими здійснюється підготовка здобувачів вищої освіти. Проте підготовка магістрів ГЗ здійснюється лише в одному немедичному ВН3 України за спеціальністю «Менеджмент організацій і адміністрування (в охороні здоров'я)», що не забезпечує сучасні потреби галузі та суспільства.

Аналіз європейського досвіду визначення потреби в кадрах для служби ГЗ на прикладі Нідерландів та структур навчальних планів підготовки фрахівців із ГЗ виявив, що в країнах Європейського Союзу відсутня спільна програма підготовки таких фрахівців, а посадові обов'язки і фахові вимоги для їх підготовки суттєво відрізняються в кожній окремій країні.

3 огляду на існуючі виклики і загрози для ГЗ, глобальні тенденції та національний контекст, необхідне фрормування нових інституційних структур з підготовки фрахівців ГЗ, обґрунтування і розробка нових навчальних планів підготовки магістрів ГЗ.

Перспективи подальших досліджень. Враховуючи євроінтеграційний вектор розвитку України, пріоритетність профрілактичного напряму національної системи охорони здоров'я та фрормування нової служби громадського здоров'я, подальшого дослідження потребує питання фрормування кадрової політики в громадському здоров'ї. Поглибленого вивчення вимагають питання планування потреби в кадрах громадського здоров'я, їх підготовки, розстановки, мотивації тощо.

\section{Список літератури}

1. Актуальні проблеми та сучасні стратегії підготовки кадрів для сфери громадського здоров'я в контексті Європейської політики «Здоров'я - 2020» / Грузєва Т. С. [та ін.] // Матеріали доповіді. - Київ, 2016.

2. Громадське здоров'я: підручник для студентів вищих медичних навчальних закладів. - Вінниця : Нова Книга, 2011. $-560 \mathrm{c}$.

3. Грузєва Т. С. Обґрунтування фрункціонально-структурної моделі системи кадрового забезпечення охорони здоров'я фрахівцями мікробіологічного профрілю / Т. С. Грузєва, В. В. Мельник // Східноєвропейський журн. громад. здоров'я. - 2015. - № 2 (23). - С. 65-75.

4. Гульчій О. П. Громадське здоров'я у надійних руках? [Електронний ресурс] / О. П. Гульчій // Ваше здоров'я. - 2016. № 7-8 (1343-1344). - С. 10-11. - Режим доступу : https://issuu.com/vzkievua/docs/vz_7-8_2016

5. Дисципліни, що пропонуються для вивчення 8.03060101 «Менеджмент організацій і адміністрування (в охороні здоров я)» [Електронний ресурс]. - Режим доступу : http://www.ukma.edu.ua/ects/index.php/fsnst/135-menedzhmentoz 6. Кадри вирішують долю реформи / В. Лазоришинець [та ін.] // Ваше здоров'я. - 2013. - 8 лют. - №5/6. - С. 6-7.

7. Кадровий потенціал медичної галузі України: десятирічна динаміка кількісних та якісних показників / Л. О. Литвинова [та ін.] // Східноєвропейський журн. громад. здоров'я. - 2015. - № 2. - С. 168-169. 
8. Князевич В. М. Перспективи розвитку публічного управління у сфері громадського здоров'я України в умовах системних змін / В. М. Князевич, Т. П. Авраменко, В.В.Короленко // Вісник НАДУ при Президентові України. - 2016. № 1. - С. 56-65. [Електронний ресурс]. - Режим доступу : http://visnyk.academy.gov.ua/wp-content/uploads/2016/05/ Du_2016_1_07.pdf

9. Концепція розвитку системи громадського здоров'я в Україні. - 2016. [Електронний ресурс]. - Режим доступу : http://moz.gov.ua/docfiles/Pro_20160309_0_dod.pdf

10. Мельник В. В. Наукове обґрунтування удосконалення кадрового забезпечення системи громадського здоров'я України фрахівцями мікробіологічного профрілю в умовах реформування [Текст]: авторефр. дис. ... канд. мед. наук : 14.02.03 / В. В. Мельник. - 2015. - 24 с.

11. Мельник В. В. Особливості забезпечення фрахівцями мікробіологічного профрілю системи громадського здоров'я в Україні / В. В. Мельник, Т. С. Грузєва // Україна. Здоров'я нації. - 2015. - № 3. - С. 82-88.

12. Мельник В. В. Удосконалення кадрового забезпечення системи громадського здоров'я України фрахівцями мікробіологічного профрілю в умовах реформування [Електронний ресурс] / В. В. Мельник, Т. С. Грузєва, В. П. Широбоков // Ліки України плюс. - 2015. - № 2 (23). - С. 43-46. - Режим доступу : http://www.health-medix.com/ articles/liki_ukr_plus/ 2015-07-10/18.pdf

13. Національна стратегія реформування системи охорони здоров'я України на період 2015-2020 рр. - Київ, 2014. C. 1-41. [Електронний ресурс]. - Режим доступу : http://healthsag.org.ua/wp-content/uploads/2014/11/Strategiya_UKR. pdf

14. Перелік ступенів та спеціальностей, за якими оголошується прийом на навчання, ліцензовані обсяги та нормативні терміни навчання. Додаток 1 до Правил прийому до НаУКМА у 2016 році [Електронний ресурс]. - Режим доступу: http://www.ukma.edu.ua/images/docs/admission/2016pravyla/dodatok_1.pdf.pdf

15. Повідомлення про оприлюднення проекту Концепції розвитку системи громадського здоров'я в Україні [Електронний ресурс]. - Режим доступу : http://moz.gov.ua/ua/portal/Pro_20160309_0.html

16. Про внесення змін до постанови Кабінету Міністрів України від 29 квітня 2015 р. № 266 : постанова Кабінету Міністрів України від 01.02.2017 р. № 53 [Електронний ресурс]. - Режим доступу : http://www.kmu.gov.ua/control/uk/ cardnpd?docid=248149695

17. Про Стратегію сталого розвитку «Україна-2020» : Указ Президента України від 12 січня 2015 р. №5/2015 [Електронний ресурс]. - Режим доступу : http://zakon5.rada.gov.ua/laws/show/5/2015.

18. Сучасні завдання вищої медичної освіти та кадрового забезпечення рефрормування галузі [Електронний ресурс]/ Т. М. Старча, О. П. Волосовець, І. В. Клоченко [та ін.]. - Режим доступу: http://www.umsa.edu.ua/volosovets 2015.pdf 19. Угода про асоціацію між Україною, з однієї сторони, та Європейським Союзом, Європейським співтовариством 3 атомної енергії і їхніми державами-членами, з іншої сторони [Електронний ресурс]. - Режим доступу : http://zakon5. rada.gov.ua/laws/show/984_011.

20. Щорічна доповідь про стан здоров'я населення, санітарно-епідемічну ситуацію та результати діяльності системи охорони здоров'я України. 2015 рік / за ред. В. В. Шафранського; МОЗ України, ДУ «УІСД МОЗ України». - Київ, 2016. - 452 с. [Електронний ресурс]. Режим доступу: http://www.uiph.kiev.ua/dawnload/Vidavnictvo/Shchorichna\%20 dopovid/Щорічна\%20доповідь.2016.pdf.

21. Beaglehole R. Public health workforce: challenges and policy issues / R. Beaglehole, M.R. Dal Poz // Hum Resour Health. - 2003. - Vol. 1 (1). - P. 4.

22. Education and training of public health professionals in the European Region: variation and convergence / BjegovicMikanovic V., Vukovic D., Otok R. [et al.] // Int. J. Public Health. -2013. - Vol. 58 (6). - P. 801-10. doi: 10.1007/s00038012-0425-2. Epub 2012 Nov 7.

23. Facets of Public Health in Europe. Edited by Bernd Rechel and Martin McKee. Published by Open University Press. European Observatory on Health Systems and Policies Series. 2014, 320 p. [Electronic resource]. - Access mode: http:// www.euro.who.int/_data/assets/pdf_file/0003/271074/Facets-of-Public-Health-in-Europe.pdf

24. Global strategy on human resources for health: Workforce 2030. Draft December 2015 [Electronic resource]. - URL : http://www.who.int/hrh/resources/WHO_GSHRH_DRAFT_05Jan16.pdf?ua=1, accessed 11 April 2016.

25. Goodman J. Public health workforce capacity building /J. Goodman, J. Overall, T. Tulchinsky. - Paris : ASPHER, 2008. 26. How to characterize the public health workforce based on essential public health operations? environmental public health workers in the Netherlands as an example / M. Jambroes, R. van Honschooten, J. Doosje [et al.] // BMC Public Health. 2015. - Vol. 15. - P. 750. doi:10.1186/s12889-015-2095-5 https://bmcpublichealth.biomedcentral.com/articles/10.1186/ s12889-015-2095-5

27. Paccaud F. Workforce in Switzerland: are public health workers lacking? [Electronic resource] / F. Paccaud, A. Weihofen, M. Frank // Int. J. Public Health. - 2013. - Vol. 58. - P. 799. doi:10.1007/s00038-013-0481-2 Open access: http://link. springer.com/article/10.1007\%2Fs00038-013-0481-2

28. Review of Public Health Capacity in the EU / Aluttis C., Chiotan C., Michelsen M. [et al.]. - Luxembourg : Published by the European Commission Directorate General for Health and Consumers, 2013.

29. The 2014 update, Global Health Workforce Statistics, World Health Organization, Geneva. http://www.who.int/hrh/ statistics/hwfstats/

30. WHO Regional Committee for Europe resolution EUR/RC61/R2 on strengthening public health capacities and services in Europe: a framework for action. - Copenhagen : WHO Regional Office for Europe, 2011.

31. World Health Statistics 2016: Monitoring health for the SDGs [Electronic resource]. - URL : http://www.who.int/gho/ publications/world_health_statistics/2016/whs2016_AnnexA_HealthWorkforce.pdf. 


\section{References}

1. Gruzieva T.S. [et al] (2016). Actualni problemy ta suchasni strategiji pidgotovky kadriv dlia sfery hromadskogo zdorovia v konteksti Evropejskoji polityky 'Zdorovia-2020' [Actual problems and modern strategies in staff training for public health service in the context of European policy 'Health - 2020'] [presentation], Kyiv [in Ukrainian].

2. Moskalenko V.F. [et al] (2011). Hromadske zdorovia: pidruchnyk dlia studentiv vyshchykh medychnykh navchalnykh zakladiv [Public Health: textbook for students of higher medical educational establishments] Vinnytsia, Ukraine, Nova Knyga, p. 560 [in Ukrainian].

3. Gruzieva T.S., Melnyk V.V. (2015). Obgruntuvannya funktsional'no-strukturnoyi modeli systemy kadrovoho zabezpechennya okhorony zdorovia fakhivtsiamy mikrobiolohichnoho profiliu [Justification of functional-structural model of staffing health professionals in microbiology]. Eastern-European Journal of Public Health, 2 (23), pp. 65-75 [in Ukrainian].

4. Hulchii O.P. (2016) Hromadske zdorovia u nadiinykh rukakh? [Is public health in good hands?]. Your Health, 7-8 (1343-1344), pp.10-11 [in Ukrainian]. Available at : https://issuu.com/vzkievua/docs/vz_7-8_2016

5. Dystsypliny, shcho proponuiutsia dlia vyvchennia 8.03060101 «Menedzhment orhanizatsii $\mathrm{i}$ administruvannia (v okhoroni zdorov ya)» [Subjects for the study of 8.03060101 «Management and Administration (in public health)»]. [in Ukrainian]. Available at : http://www.ukma.edu.ua/ects/index.php/fsnst/135-menedzhmentoz

6. Lazoryshynets, V. et al (2013). Kadry` vy`rishuyut` dolyu reform [Staff decides the fate of reform]. Vashe zdorov'ya Your Health №5/6, 6-7 [in Ukrainian].

7. Lytvynova L.O. [et al] (2015). Kadrovyi potentsial medychnoi haluzi Ukrainy: desiatyrichna dynamika kilkisnykh ta yakisnykh pokaznykiv [Staff potential in health care of Ukraine: ten-year dynamics of quantitative and qualitative indicators] Eastern-European Journal of Public Health, 2, pp. 168-169 [in Ukrainian].

8. Kniazevych V.M., Avramenko T.P., Korolenko V.V. (2016). Perspektyvy rozvytku publichnoho upravlinnia u sferi hromadskoho zdorovia Ukrainy $v$ umovakh systemnykh zmin [Prospects for the development of public administration in public health Ukraine in terms of system changes]. Visnyk NADU pry Prezydentovi Ukrainy, 1, pp. 56-65 [in Ukrainian]. Available at : http://visnyk.academy.gov.ua/wp-content/uploads/2016/05/Du_2016_1_07.pdf

9. Kontseptsiia rozvytku systemy hromadskoho zdorovia v Ukraini (2016) [Concepts of the development of health care system in Ukraine] [in Ukrainian]. Available at : http://moz.gov.ua/docfiles/Pro_20160309_0_dod.pdf

10. Melnyk V.V. (2015). Naukove obgruntuvannia udoskonalennia kadrovoho zabezpechennia systemy hromadskoho zdorovia Ukrainy fakhivtsiamy mikrobiolohichnoho profiliu v umovakh reformuvannia [Scientific justification of improvement staffing in public health with experts for microbiology of Ukraine in reforming], 24 p. [in Ukrainian].

11. Melnyk V.V., Gruzieva T.S. (2015). Osoblyvosti zabezpechennia fakhivtsiamy mikrobiolohichnoho profiliu systemy hromadskoho zdorovia $v$ Ukraini [Features of staffing of specialists in microbiology for public health in Ukraine]. Ukraine. Health of the Nation, 3, pp.82-88. [in Ukrainian].

12. Melnyk V.V., Gruzieva T.S., Shyrobokov V.P. (2015). Udoskonalennia kadrovoho zabezpechennia systemy hromadskoho zdorovia Ukrainy fakhivtsiamy mikrobiolohichnoho profiliu v umovakh reformuvannia [Improving of staffing with experts in microbiology for public health system of Ukraine in reforming] Liky Ukrainy plus, 2 (23), pp.43-46. [in Ukrainian]. Available at : http://www.health-medix.com/articles/liki_ukr_plus/2015-07-10/18.pdf

13. Natsionalna stratehiia reformuvannia systemy okhorony zdorovia Ukrainy na period 2015-2020 rr. [The National Strategy for Health Reform Ukraine for the period 2015-2020.], Kyiv, pp. 1-41. [in Ukrainian]. Available at : http://healthsag. org.ua/wp-content/uploads/2014/11/Strategiya_UKR.pdf

14. Perelik stupeniv ta spetsialnostei, za yakymy oholoshuietsia pryiom na navchannia, litsenzovani obsiahy ta normatyvni terminy navchannia. / Dodatok 1 do Pravyl pryiomu do NaUKMA u 2016 rotsi [The list of degrees and specialties, which announced admit students, licensed volumes and regulatory terms of training. / Annex 1 to the admission to NaUKMA 2016], Available at : http://www.ukma.edu.ua/images/docs/admission/2016pravyla/dodatok_1.pdf.pdf

15. Povidomlennia pro opryliudnennia proektu Kontseptsii rozvytku systemy hromadskoho zdorovia v Ukraini [Notice of publication of the project of the Concept of public health in Ukraine. -] (2016). Available at : http://moz.gov.ua/ua/portal/ Pro_20160309_0.html

16. Postanova Kabinetu Ministriv Ukrainy vid 01 liutoho 2017 r. \# 53 «Pro vnesennia zmin do postanovy Kabinetu Ministriv Ukrainy vid 29 kvitnia 2015 r. \# 266» [Cabinet of Ministers of Ukraine, 01 February 2017 r. Number 53 «On Amendments to the Cabinet of Ministers of Ukraine of 29 April 2015 r. Number 266»] / Available at : http://www.kmu.gov. ua/control/uk/cardnpd?docid=248149695.

17. Ukaz Prezydenta Ukrainy vid 12 sichnia 2015 r. \#5/2015 «Pro Stratehiiu staloho rozvytku «Ukraina - 2020»» [The President of Ukraine Decree of 12 January 2015 r. №5 / 2015 «On the Strategy for Sustainable Development «Ukraine 2020 «]. Available at : http://zakon5.rada.gov.ua/laws/show/5/2015

18. Starcha T.M., Volosovets O.P., Klochenko I.V. [et al.] (2015). Suchasni zavdannia vyshchoi medychnoi osvity ta kadrovoho zabezpechennia reformuvannia haluzi [Current objectives of higher medical education and staffing reform], [text]. Available at : http://www.umsa.edu.ua/volosovets_2015.pdf

19. Uhoda pro asotsiatsiiu mizh Ukrainoiu, z odniiei storony, ta Yevropeiskym Soiuzom, Yevropeiskym spivtovarystvom $z$ atomnoi enerhii i yikhnimy derzhavamy-chlenamy, z inshoi storony [Association Agreement between Ukraine, on the one hand, and the European Union, the European Atomic Energy Community and their Member States, on the other hand]. Available at : http://zakon5.rada.gov.ua/laws/show/984_011

20. Shafranskyi V.V. [et al]. (2016). Shchorichna dopovid pro stan zdorovia naselennia, sanitarno-epidemichnu sytuatsiiu ta rezultaty diialnosti systemy okhorony zdorovia Ukrainy. 2015 rik [Annual report on the state of health, sanitary and epidemiological situation and results of the healthcare system of Ukraine. 2015], Kyiv, 452 p. Available at : http://www.uiph. kiev.ua/dawnload/Vidavnictvo/Shchorichna\%20dopovid/Щорічна\%20доповідь.2016.pdf 
21. Beaglehole R, Dal Poz MR. Public health workforce: challenges and policy issues. Hum Resour Health. 2003;1(1):4.

22. Bjegovic-Mikanovic V, Vukovic D, Otok R, Czabanowska K, Laaser U. Education and training of public health professionals in the European Region: variation and convergence. / Int J Public Health. 2013 Dec;58(6):801-10. doi: 10.1007/s00038-012-0425-2. Epub 2012 Nov 7.

23. Facets of Public Health in Europe. Edited by Bernd Rechel and Martin McKee. Published by Open University Press. European Observatory on Health Systems and Policies Series. 2014, 320 p. Available at : http://www.euro.who.int/_data/ assets/pdf_file/0003/271074/Facets-of-Public-Health-in-Europe.pdf

24. Global strategy on human resources for health: Workforce 2030. Draft December 2015 Available at: http://www. who.int/hrh/resources/WHO_GSHRH_DRAFT_05Jan16.pdf?ua=1, accessed 11 April 2016.

25. Goodman J, Overall J, Tulchinsky T: Public health workforce capacity building. Paris: ASPHER; 2008.

26. Jambroes M., van Honschooten R., Doosje J., Stronks K., Essink-Bot M.L. How to characterize the public health workforce based on essential public health operations? environmental public health workers in the Netherlands as an example. BMC Public Health 2015, 15:750 doi:10.1186/s12889-015-2095-5 Available at : https://bmcpublichealth. biomedcentral.com/articles/10.1186/s12889-015-2095-527.

27. Paccaud, F., Weihofen, A. \& Frank, M. Int J Public Health Workforce in Switzerland: are public health workers lacking? Public Health (2013) 58: 799. doi:10.1007/s00038-013-0481-2 Available at : http://link.springer.com/article/10.1 007\%2Fs00038-013-0481-2

28. Aluttis C, Chiotan C, Michelsen M, Costongs C, Brand H. Review of Public Health Capacity in the EU. In: Luxembourg: Published by the European Commission Directorate General for Health and Consumers. 2013.

29. The 2014 update, Global Health Workforce Statistics, World Health Organization, Geneva. Available at : http://www. who.int/hrh/statistics/hwfstats/

30. WHO Regional Committee for Europe resolution EUR/RC61/R2 on strengthening public health capacities and services in Europe: a framework for action. In. Copenhagen: WHO Regional Office for Europe; 2011.

31. World Health Statistics 2016: Monitoring health for the SDGs. Available at: http://www.who.int/gho/publications/ world_health_statistics/2016/whs2016_AnnexA_HealthWorkforce.pdf

\section{АНАЛИЗ КАДРОВОГО ОБЕСПЕЧЕНИЯ И ПРИНЦИПОВ ПОДГОТОВКИ СПЕЦИАЛИСТОВ ДЛЯ СЛУЖБЫ ОБЩЕСТВЕННОГО ЗДОРОВЬЯ В УКРАИНЕ}

Т.С. Грузева, Л.И. Галиенко, Е.Я. Антонюк, С.В. Власенко

Национальный медицинский университет имени А.А. Богомольца, г. Киев, Украина

Цель: обоснование кадрового обеспечение службы общественного здоровья Украины в условиях ресормирования отрасли.

Материалы и методы. Изучались данные государственной статистической отчетности, базы «ЗДВ» Европейского регионального бюро ВО3, World Health Statistics 2016. Использовались методы: статистический, библиосемантический, экспертных оценок, системного подхода.

Результаты. Анализ кадрового обеспечения здравоохранения Украины указывает на снижение показателей обеспечения населения врачами, в т. ч. специалистами санитарно-эпидемиологического профиля. В течение 20102015 гг. обеспеченность врачами уменьшилась на 16,3\%, в т. ч. санитарными врачами - на 14,7\%.

На основе анализа контингента студентов, которые обучались в 2015 г. по специальности «Медикопросрилактическое дело» в ВМУЗ Украины на додипломном уровне, установлено, что план подготовки по государственному заказу за последние три года был уменьшен в три раза. Специальность «Общественное здоровье» включена в перечень отраслей знаний и специальностей, по которым проводится подготовка соискателей высшего образования. Однако подготовка магистров общественного здоровья проводится только в одном немедицинском ВУЗ Украины, только по специальности «Менеджмент организаций и администрирования (в здравоохранении)», что не обеспечивает современные нужды отрасли и общества.

Анализ европейского опыта показал, что в странах Европейского союза отсутствует общая программа подготовки таких специалистов, а должностные инструкции и профессиональные требования для подготовки специалистов существенно отличаются в каждой отдельной стране.

Выводы. Учитывая существующие вызовы и угрозы для общественного здоровья, глобальные тенденции и национальный контекст, необходимо фрормирование новых институциональных структур по подготовке специалистов общественного здоровья, обоснование и разработка новых учебных планов подготовки магистров общественного здоровья.

КЛЮЧЕВЫЕ СЛОВА: служба общественного здоровья, кадровое обеспечение, санитарный врач, подготовка кадров.

\section{ANALYSIS OF STAFFING AND PRINCIPLES OF TRAINING FOR PUBLIC HEALTH SERVICE IN UKRAINE}

T.S. Gruzieva, L.I. Galiyenko, O.Ya. Antonyuk, S.V. Vlasenko

Bogomolets National Medical University, Kyiv, Ukraine

Aim: justification of staffing for public health service in Ukraine during reforming of health care. 
Materials: data of state statistical reports, European Health for All database (HFA-DB) of Regional Office for Europe, World Health Statistics 2016.

Methods: statistical, bibliosemantic, expert assessments, systematic approach.

Results. Analysis of staffing of health care in Ukraine indicates a decrease in physician density, including public health physicians (PHP). Within 2010-2015 physician density decreased by 16.3\%, including PHP - by 14.7\%.

Based on analysis of contingent of students who studied for specialty «medical preventive care» (undergraduate training) at medical universities in Ukraine in 2015, it was found that for the last 3 years number of students who study by the plan according to state order approved by Ministry of Health (budget form of study), decreased three times. Specialty «public health» was added to the list of disciplines and specialties according to which undergraduate study of students is organized. However, training of Master of Public Health is performed only at one non-medical university in Ukraine only in specialty «management of organization and administration (in health care)» which does not provide up-to-date needs of health care and society.

Analysis of the European experience has shown that there is no common curriculum for training such professionals in European Union, job descriptions and qualifications for training specialists vary significantly in each separate country as well.

Conclusions. In view of existing challenges and threats to public health, global trends and national context, it is necessary to establish new institutional structures for training public health professionals, justification and development of new training curriculum for Master of Public Health.

KEY WORDS: public health service, staffing, public health physician, training.

Рукопис надійшов до редакції 02.03.2017 p.

Відомості про авторів:

Грузєва Тетяна Степанівна - д.мед.н., проф., завідувач кафедри соціальної медицини та громадського здоров'я Національного медичного універститету імені О.О. Богомольця.

Галієнко Людмила Іванівна - к.мед.н., доцент, професор кафедри соціальної медицини та громадського

здоров'я Національного медичного універститету імені О.О. Богомольця.

Антонюк Олена Ярославівна - асистент кафедри соціальної медицини та громадського здоров'я Національного медичного універститету імені О.О. Богомольця.

Власенко Світлана Вікторівна - асистент кафедри соціальної медицини та громадського здоров'я Національного медичного універститету імені О.О. Богомольця. 